\title{
Relationship between parathyroid calcium-sensing receptor expression and potency of the calcimimetic, cinacalcet, in suppressing parathyroid hormone secretion in an in vivo murine model of primary hyperparathyroidism
}

Takehisa Kawata ${ }^{1,2}$, Yasuo Imanishi ${ }^{1}$, Keisuke Kobayashi ${ }^{1}$, Takao Kenko ${ }^{3}$, Michihito Wada ${ }^{2}$, Eiji Ishimura ${ }^{4}$, Takami Miki ${ }^{5}$, Nobuo Nagano ${ }^{2}$, Masaaki Inaba ${ }^{1}$, Andrew Arnold ${ }^{6}$ and Yoshiki Nishizawa ${ }^{1}$

${ }^{1}$ Department of Metabolism, Endocrinology and Molecular Medicine, Osaka City University Graduate School of Medicine, Osaka, Japan, ${ }^{2}$ Pharmaceutical Development Laboratories, Kirin Brewery Co., Ltd., Takasaki, Japan, ${ }^{3}$ Osaka City University Medical School for Technical Assistance, Departments of ${ }^{4}$ Nephrology, and ${ }^{5}$ Geriatrics and Neurology, Osaka City University Graduate School of Medicine, Osaka, Japan and ${ }^{6}$ Center for Molecular Medicine, University of Connecticut Health Center, Farmington, CT.

(Correspondence should be addressed to Y Imanishi, Department of Metabolism, Endocrinology and Molecular Medicine, Osaka City University Graduate School of Medicine, 1-4-3, Asahi-machi, Abeno-ku, Osaka 545-8585, Japan; Email: imanishi@med.osaka-cu.ac.jp)

\begin{abstract}
Cinacalcet $\mathrm{HCl}$, an allosteric modulator of the calcium-sensing receptor (CaR), has recently been approved for the treatment of secondary hyperparathyroidism in patients with chronic kidney disease on dialysis, due to its suppressive effect on parathyroid hormone (PTH) secretion. Although cinacalcet's effects in patients with primary and secondary hyperparathyroidism have been reported, the crucial relationship between the effect of calcimimetics and CaR expression on the parathyroid glands requires better understanding. To investigate its suppressive effect on PTH secretion in primary hyperparathyroidism, in which hypercalcemia may already have stimulated considerable CaR activity, we investigated the effect of cinacalcet $\mathrm{HCl}$ on PTH-cyclin D1 transgenic mice (PC2 mice), a model of primary hyperparathyroidism with hypo-expression of $\mathrm{CaR}$ on their parathyroid glands. A single administration of $30 \mathrm{mg} / \mathrm{kg}$ body weight (BW) of cinacalcet $\mathrm{HCl}$ significantly suppressed serum calcium (Ca) levels $2 \mathrm{~h}$ after administration in 65- to 85-week-old PC2 mice with chronic biochemical hyperparathyroidism. The percentage reduction in serum PTH was significantly correlated with CaR hypo-expression in the parathyroid glands. In older PC2 mice (93-99 weeks old) with advanced hyperparathyroidism, serum $\mathrm{Ca}$ and PTH levels were not suppressed by $30 \mathrm{mg}$ cinacalcet $\mathrm{HCl} / \mathrm{kg}$. However, serum $\mathrm{Ca}$ and PTH levels were significantly suppressed by $100 \mathrm{mg} / \mathrm{kg}$ of cinacalcet $\mathrm{HCl}$, suggesting that higher doses of this compound could overcome severe hyperparathyroidism. To conclude, cinacalcet $\mathrm{HCl}$ demonstrated potency in a murine model of primary hyperparathyroidism in spite of any presumed endogenous CaR activation by hypercalcemia and hypo-expression of $\mathrm{CaR}$ in the parathyroid glands.
\end{abstract}

European Journal of Endocrinology 153 587-594

\section{Introduction}

Primary hyperparathyroidism is characterized by hyperfunctioning parathyroid tissue that responds with decreased sensitivity to extracellular calcium (Ca) concentration in suppressing parathyroid hormone (PTH) secretion, resulting in the development of hypercalcemia. Sporadic nonfamilial parathyroid adenomas are the most frequent cause of primary hyperparathyroidism. Two specific genes have been identified as participating in their tumorigenesis; the cyclin D1/PRAD1 oncogene (1) and the multiple endocrine neoplasia type 1 (MEN1) tumor-suppressor gene $(2,3)$. Other oncogenes and/or tumorsuppressor genes, still unidentified, also contribute to the tumorigenesis of parathyroid adenomas $(3,4)$. Even though no mutations of the calcium-sensing receptor $(\mathrm{CaR})$ gene were detected in parathyroid tumors $(5,6)$, reduced $\mathrm{CaR}$ expression in parathyroid glands has been observed in primary and secondary hyperparathyroidism $(7,8)$. CaR on the parathyroid chief cells is the primary PTH regulator, detecting extracellular Ca levels, working quickly when activated by serum $\mathrm{Ca}$ elevation through intracellular signaling pathways to suppress PTH secretion (9, 10). An abnormal secretory set-point of the PTHCa sigmoidal curve was also associated with reduced CaR expression in parathyroid glands in vivo in CaRknockout mice (11) and a murine model of primary hyperparathyroidism (12). 
Parathyroidectomy is currently the only definitive treatment for moderate to severe primary hyperparathyroidism (13). Some patients with asymptomatic primary hyperparathyroidism who do not meet the guidelines for parathyroidectomy, and are monitored without surgical therapy, develop bone and kidney complications $(13,14)$. Although bisphosphonates, such as alendronate (15), or estrogen therapies (16) have met with some success in preventing bone loss, other complications such as nephrocalcinosis may not be prevented. Other patients clearly meet the criteria for definitive surgical therapy but either refuse or are not candidates for surgery for other reasons. Calcimimetic compounds are low molecular weight phenylalkylamine derivatives that act as allosteric modulators of the CaR (17). These compounds enhance the sensitivity of the $\mathrm{CaR}$ to extracellular $\mathrm{Ca}$, thus exerting a suppressive effect on PTH secretion. Cinacalcet $\mathrm{HCl}$ has recently been approved for the treatment of secondary hyperparathyroidism in patients on maintenance hemodialysis, and has been shown to reduce PTH secretion both in vitro (bovine parathyroid cell assay) and in vivo (normal rats) (18). Although cinacalcet $\mathrm{HCl}$ has met with success as a novel therapeutic agent for the treatment of secondary (19-23) and primary $(24,25)$ hyperparathyroidism in clinical studies, the relationship between the effect of this compound and $\mathrm{CaR}$ expression on the abnormal parathyroid glands is unknown.

The aim of this study was to evaluate the effects of cinacalcet $\mathrm{HCl}$ in the suppression of serum PTH and Ca levels in vivo in a murine model of primary hyperparathyroidism and also to investigate its molecular mechanism. We aimed to learn more about the effect of cinacalcet on parathyroid glands with reduced $\mathrm{CaR}$ expression.

\section{Materials and methods}

\section{Materials}

Cinacalcet HCl $(\alpha R)-(-)-\alpha$-methyl-N-[3-[3-trifluoromethylphenyl]propyl]-1napthalenemethanamine hydrochloride was generated by Kirin Brewery Co. Ltd (Takasaki, Japan). Methylcellulose was obtained from Sigma (St Louis, MO, USA). NPS Pharmaceutical, Inc. (Salt Lake City, UT, USA) kindly provided anti-CaR antibody (4638 polyclonal antibody). Anti-PTH antibody was purchased from Santa Cruz Biotechnology, Inc. (Santa Cruz, CA, USA).

\section{Animals}

FVB/N background PTH-cyclin D1 transgenic mice (PC2), which exhibit parathyroid-targeted overexpression of the human cyclin D1 oncogene, were used in this study as a model of primary hyperparathyroidism (12). Offspring were genotyped by Southern blotting using human(h)-cyclin D1 cDNA as a probe (12), to select the mice bearing the transgene. All mice were provided with the commercially available rodent diet, CE-2 (Crea Japan, Inc., Tokyo, Japan), containing 1.03\% Ca and $0.97 \%$ phosphate. Food and water were available ad libitum. Studies were approved by the appropriate institutional animal care committees at Osaka City University Medical School.

\section{Experimental protocols}

Wild-type (WT) mice, 65-85 weeks old, were used for the time-course changes of serum Ca levels after the oral administration of various doses of cinacalcet $\mathrm{HCl}$. Mice were given 10, 30 or $100 \mathrm{mg}$ cinacalcet $\mathrm{HCl} / \mathrm{kg}$ body weight in $0.5 \%$ methylcellulose or vehicle, and blood samples were collected at $0,2,8$, and $24 \mathrm{~h}$ after the oral administration. Serum Ca levels were measured to determine the proper dose of cinacalcet $\mathrm{HCl}$ for mice. To examine the effects of cinacalcet $\mathrm{HCl}$, 65- to 85-week-old WT and PC2 mice, and 93- to 99-week-old PC2 mice were used for the study. The 65- to 85-week-old WT and PC2 mice were given $30 \mathrm{mg}$ cinacalcet/kg orally, and blood samples were collected at 0 and $2 \mathrm{~h}$ thereafter. The inhibitory rate of PTH secretion (\%) was defined as (PTH $2 \mathrm{~h}-$ PTH Oh) / PTH Oh $\times 100$. The 93- to 99-week-old PC2 mice were also given cinacalcet $\mathrm{HCl}$ twice, at the initial dose of $30 \mathrm{mg} / \mathrm{kg}$ followed by $100 \mathrm{mg} / \mathrm{kg}$. The interval between the first treatment $(30 \mathrm{mg} / \mathrm{kg})$ and the second treatment $(100 \mathrm{mg} / \mathrm{kg})$ was 1 week so as to wash out the effect of the first administration.

\section{Measurement of biochemical parameters}

Blood samples were collected from orbital cavities. Serum PTH was measured by a rat PTH IRMA kit (Immutopics, Inc., San Clemente, CA, USA). Serum $1,25(\mathrm{OH})_{2} \mathrm{D}$ concentrations were measured by a radioimmunoassay kit (Immunodiagnostic Systems Ltd, Boldon, Tyne and Wear, UK). Serum biochemistries, including total $\mathrm{Ca}$, phosphate, urea nitrogen (SUN) and alkaline phosphatase (ALP) were determined by a series of TESTWAKO kits (Wako Pure Chemical Industries Ltd, Osaka, Japan.).

\section{Parathyroid histology}

Resected parathyroid glands were immediately fixed in $10 \%$ formalin for 2 days, and embedded in paraffin. Total parathyroid glands were sliced into $3 \mu \mathrm{m}$-thick sections, and the number of slides that contained parathyroid tissue was counted. Every quarter section defined by a slide's number was selected for the analysis as an indicator of the parathyroid gland size. Immunohistochemistry analyses were performed followed by inactivation of intrinsic peroxidase by incubation in 3\% hydrogen peroxide diluted in methanol. Sections were then treated 
with skim milk to prevent background staining, and incubated with anti-CaR $(0.8 \mu \mathrm{g} / \mathrm{ml})$ or anti-PTH (diluted $1: 1000$ ) antibody overnight at $4{ }^{\circ} \mathrm{C}$ in a humidified chamber. After rinsing, sections were incubated with the biotinylated secondary antibody and peroxidase-conjugated streptavidin, followed by visualization by alkaline phosphatase and counter staining by hematoxylin.

The outside of the parathyroid gland was carefully traced in each slide, and a person who was blinded to the tissue samples calculated the area using Adobe Photoshop v. 5.5 software (Adobe Systems Inc., San Jose, CA, USA). The size given by pixels was changed to a millimeter ${ }^{2}$ value using NIH image 1.62 software (National Institutes of Health, Bethesda, MD, USA) and adjusted for $\mathrm{kg}$ body weight (26). The size of each gland was represented by the mean value of three slides. The unstained area was defined as the area apparently stained more faintly than the area of the clearly stained normal parathyroid gland.

\section{Statistical analyses}

Biochemical parameters between WT and PC2 mice were analyzed by the Mann-Whitney U test. Serum PTH and Ca levels pre- and post-administration of cinacalcet $\mathrm{HCl}$ were analyzed by the Wilcoxon single rank test. Parathyroid gland sizes between WT and PC2 mice were analyzed by the Mann-Whitney U test. Correlations between inhibition rates of PTH secretion and parathyroid gland sizes were analyzed by the Pearson correlation test. All the data are presented as means \pm s.E.

\section{Results}

\section{Effects of cinacalcet HCI on serum Ca levels in WT mice}

In WT mice, serum Ca levels were significantly suppressed between 2 and $8 \mathrm{~h}$ after the administration of cinacalcet $\mathrm{HCl}(30$ and $100 \mathrm{mg} / \mathrm{kg}$ ) with a return to basal levels at $24 \mathrm{~h}$ (Fig. 1). Serum Ca levels were not significantly affected by the administration of cinacalcet $\mathrm{HCl}$ at $10 \mathrm{mg} / \mathrm{kg}$.

\section{Serum parameters in PC2 mice}

PC2 mice aged 65-85 weeks showed significant increases in serum Ca, PTH, and $1,25(\mathrm{OH})_{2} \mathrm{D}$ levels and a significant decrease in serum phosphate levels compared with age-matched WT mice, indicating that the PC2 mice had developed biochemical primary hyperparathyroidism, as expected, at this age (Table 1). PC2 mice grew normally, and showed no difference in weight and SUN values compared with WT mice. Older PC2 mice aged 93-99 weeks showed more severe hyperparathyroidism with significantly higher serum Ca and PTH levels than younger PC2 mice aged 65-85 weeks. Older WT mice (93-99 weeks old) had similar levels of these parameters as the younger mice (65-85 weeks old) (data not shown). No increment in SUN was observed in the mice used in this study, confirming that hyperparathyroidism was generated primarily and not secondarily by renal failure.

\section{Administration of cinacalcet HCI to PC2 mice}

Oral administration of $30 \mathrm{mg}$ cinacalcet $\mathrm{HCl} / \mathrm{kg}$ significantly suppressed serum Ca levels in both 65- to 85week-old PC2 and WT mice by $2 \mathrm{~h}$ after administration (Fig. 2A). Serum PTH levels were also suppressed significantly by $30 \mathrm{mg}$ cinacalcet $\mathrm{HCl} / \mathrm{kg}$, from $66 \pm 7 \mathrm{pg} / \mathrm{ml}$ to $11 \pm 3 \mathrm{pg} / \mathrm{ml}$, and from $138 \pm 20 \mathrm{pg} / \mathrm{ml}$ to $89 \pm 15 \mathrm{pg} / \mathrm{ml}$ in $\mathrm{WT}$ and $\mathrm{PC} 2$ mice respectively. The inhibitory rates of PTH secretion (\%) were $82 \pm 6$ and $36 \pm 7$ in WT and PC2 mice respectively, indicating that the suppressive effect of cinacalcet $\mathrm{HCl}$ on $\mathrm{PTH}$ was significantly weaker in PC2 mice than in WT mice (Fig. 2B). Serum phosphate and ALP levels showed a tendency to decrease after administration of cinacalcet $\mathrm{HCl}$, although this was not statistically significant (data not shown).

\section{CaR expression on parathyroid glands by immunohistochemical analysis and its correlation with the effect of cinacalcet HCI administration}

The parathyroid gland sizes of 65- to 85-week-old PC2 mice were 3.14 times larger than those of age-matched WT mice (Fig. 3). Areas of reduced CaR expression were also larger in parathyroid glands from PC2 mice compared with those from WT mice (Fig. 3). In parathyroid glands from WT mice, no focal regions of reduced CaR expression areas existed such as those seen in PC2 mice (Fig. 4c); however, small numbers of individual cells, which were not clustered as in PC2 mice, were also regarded as hypo-expression regions in WT mice. Reduced CaR expression areas had an adenomatous appearance with a multilobular, tubular pattern, which was encapsulated on hematoxylin-eosin staining

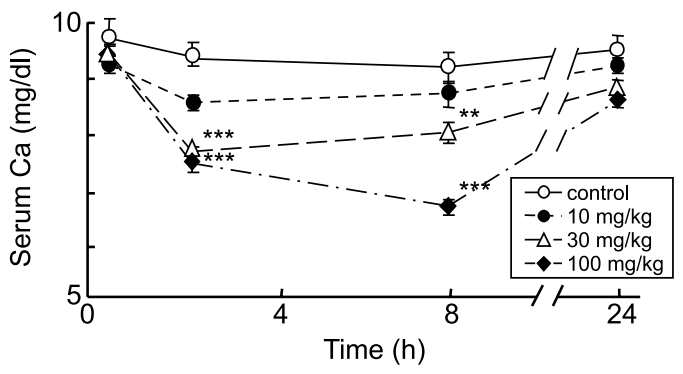

Figure 1 Serum Ca levels in WT mice after bolus administration of vehicle or estimated doses of cinacalcet $\mathrm{HCl}$. Values represent means \pm S.E., $n=3$ or $4 /$ group. ${ }^{* *} P<0.01$, ${ }^{* * *} P<0.001$ compared with vehicle (control) (Mann-Whitney $U$ test). 
Table 1 Serum biochemistries of WT and PC2 mice. Values are means \pm S.E.

\begin{tabular}{|c|c|c|c|}
\hline & $\begin{array}{c}\text { WT 65-85 weeks } \\
(n=9)\end{array}$ & $\begin{array}{c}\text { PC 65-85 weeks } \\
(n=11)\end{array}$ & $\begin{array}{c}\text { Old PC2 93-99 weeks } \\
\quad(n=8)\end{array}$ \\
\hline Body weight (g) & $36 \pm 2$ & $34 \pm 1$ & $30 \pm 2^{*}$ \\
\hline $\mathrm{Ca}(\mathrm{mg} / \mathrm{dl})$ & $8.1 \pm 0.1$ & $10.7 \pm 0.3^{* \star *}$ & $11.6 \pm 0.6^{\star \star \star}$ \\
\hline$P(\mathrm{mg} / \mathrm{dl})$ & $5.8 \pm 0.4$ & $4.6 \pm 0.3^{\star}$ & $4.4 \pm 0.7$ \\
\hline PTH (pg/ml) & $65 \pm 7$ & $137 \pm 19^{\star *}$ & $220 \pm 30^{\star * \star \#}$ \\
\hline $1,25(\mathrm{OH})_{2} \mathrm{D}(\mathrm{pmol} / \mathrm{ml})$ & $233 \pm 31$ & $399 \pm 24^{\star \star \star}$ & $381 \pm 29^{\star \star}$ \\
\hline ALP $(K-A)$ & $40 \pm 3$ & $50 \pm 17$ & $66 \pm 13$ \\
\hline SUN (mg/dl) & $21 \pm 1$ & $22 \pm 1$ & $21 \pm 0.7$ \\
\hline
\end{tabular}

$\mathrm{Ca}$, total calcium; $\mathrm{P}$, phosphate; ALP, alkaline phosphatase; K-A, King-Armstrong unit; SUN, serum urea nitrogen.

${ }^{\star} P<0.05,{ }^{\star \star} P<0.01,{ }^{\star \star \star} P<0.001$ versus WT mice; $\# P<0.05$ versus $P C 2$ mice (Mann-Whitney $U$ test).

(data not shown). In these reduced CaR expression areas, PTH expression, examined by simultaneous immunostaining with anti-PTH antibody, was upregulated in PC2 mice (Fig. 4c, f). The sizes of the reduced CaR expression areas exhibited significant negative correlations with the ability of $30 \mathrm{mg}$ cinacalcet $\mathrm{HCl} / \mathrm{kg}$ to inhibit PTH secretion in PC2 mice only $(r=-0.717$, $P=0.011)$ and also in total mice examined including PC2 and WT mice $(r=-0.751, P<0.001)$ (Fig. 5).

\section{The effect of cinacalcet HCI on advanced hyperparathyroid PC2 mice}

Older PC2 mice aged 93-99 weeks, which developed more severe hyperparathyroidism, were also examined for the suppressive effect of cinacalcet $\mathrm{HCl}$. In these mice, both the size of the parathyroid glands and the size of reduced $\mathrm{CaR}$ expression areas were larger than those of 65- to 85-week-old PC2 mice (data not shown). The administration of $30 \mathrm{mg}$ cinacalcet $\mathrm{HCl} / \mathrm{kg}$ failed to suppress either serum Ca or PTH levels (Fig. 6). The same mice were given $100 \mathrm{mg}$ cinacalcet $\mathrm{HCl} / \mathrm{kg}$ after a one week washout period during which serum Ca and PTH returned to basal levels (data not shown). Cinacalcet $\mathrm{HCl}$ at a dose of $100 \mathrm{mg} / \mathrm{kg}$ significantly suppressed both serum Ca and PTH levels by $2 \mathrm{~h}$ post treatment in the mice that had been resistant to $30 \mathrm{mg}$ cinacalcet $\mathrm{HCl} / \mathrm{kg}$.

\section{Discussion}

Cinacalcet $\mathrm{HCl}$, an allosteric modulator of the calciumsensing receptor (CaR), suppresses PTH secretion and has recently been approved for the treatment of patients with secondary hyperparathyroidism on maintenance dialysis. Although the efficacy of cinacalcet in patients with primary and secondary hyperparathyroidism has been reported, the crucial relationship between the potency of calcimimetics on PTH secretion and $\mathrm{CaR}$ expression level on the parathyroid glands is as yet unknown. In this study, as CaR expression on parathyroid glands became less, the effect of cinacalcet $\mathrm{HCl}$ on the suppression of PTH was weaker in PC2 mice, a mouse model of primary hyperparathyroidism. In addition, resistance of cinacalcet $\mathrm{HCl}$ in mice with severe hyperparathyroidism induced by extraordinary hypo-expression of CaR expression, was overcome by increasing the dose of cinacalcet $\mathrm{HCl}$ administered.

In this study, we demonstrated a negative correlation between the potency of cinacalcet $\mathrm{HCl}$ on the parathyroid glands and on parathyroid CaR expression. In addition, a relative resistance to cinacalcet $\mathrm{HCl}$ was found in mice with severe hyperparathyroidism, which was overcome by increasing the dose administered.

This is the first study to examine the effect of the calcimimetic, cinacalcet $\mathrm{HCl}$, in an in vivo model of primary hyperparathyroidism, in contrast to the
A

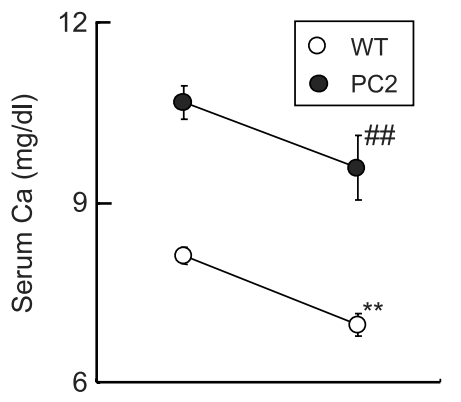

Oh

$2 \mathrm{~h}$

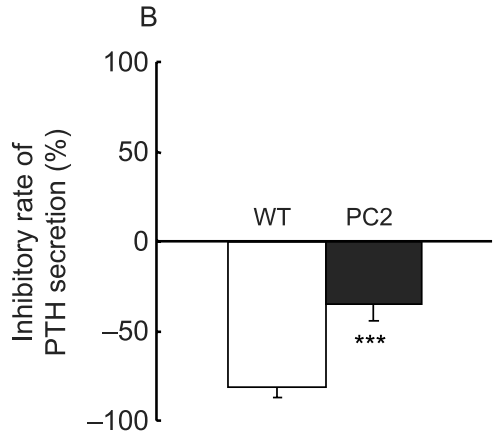

Figure 2 Effect of administration of $30 \mathrm{mg}$ cinacalcet $\mathrm{HCl} / \mathrm{kg}$ on $(\mathrm{A})$ serum $\mathrm{Ca}$ and $(B) \mathrm{PTH}$ levels in WT $(n=9)$ and PC2 $(n=11)$ mice. Values represent means \pm S.E. The inhibitory rate of $\mathrm{PTH}$ secretion (\%) was defined as (PTH $2 \mathrm{~h}-\mathrm{PTH} 0 \mathrm{~h}$ ) / PTH Oh $\times$ 100. Serum PTH levels decreased from $66 \pm 7 \mathrm{pg} / \mathrm{ml}$ to $11 \pm 3 \mathrm{pg} / \mathrm{ml}$, and from $138 \pm 20 \mathrm{pg} / \mathrm{ml}$ to $89 \pm 15 \mathrm{pg} / \mathrm{ml}$ in WT and PC2 mice respectively. The inhibitory rates of $\mathrm{PTH}$ secretion (\%) were $82 \pm 6$ and $36 \pm 7$ in WT and PC2 mice respectively. (A) ${ }^{* *} P<0.01$, \#\# $P<0.001$ compared with $0 \mathrm{~h}$ (Wilcoxon single rank test). (B) ${ }^{* * *} P<0.001$ compared with WT (Mann-Whitney U test). 


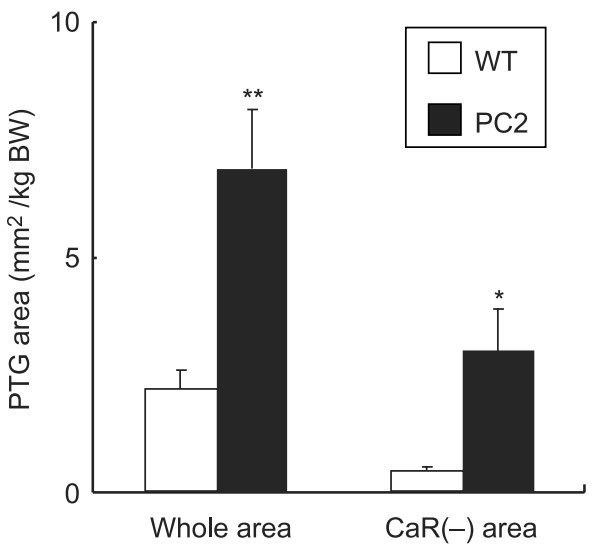

Figure 3 The sizes of whole and $\mathrm{CaR}$ reduced $(\mathrm{Ca}-)$ areas of parathyroid glands (PTG). Values represent means \pm S.E., $n=9$ in WT mice, $n=11$ in PC2 mice. ${ }^{*} P<0.05,{ }^{*} P<0.01$ compared with WT mice (Mann-Whitney $U$ test).

well-documented effects of these agents in secondary hyperparathyroidism. In uremic 5/6 NX rat models, hypocalcemia is observed due to decreased $1,25(\mathrm{OH})_{2} \mathrm{D}$ levels and suppressed intestinal Ca absorption (27). In such relative hypocalcemic to normocalcemic status, calcimimetics effectively suppress PTH secretion and parathyroid cell proliferation $(28-30)$. In patients on maintenance hemodialysis, cinacalcet $\mathrm{HCl}$ successfully reduced serum PTH resulting in a decrease in the $\mathrm{Ca} \times$ phosphorus product (22).

Recently, the beneficial effect of cinacalcet $\mathrm{HCl}$ in normalizing serum Ca levels by suppressing serum PTH levels was demonstrated in patients with primary hyperparathyroidism, who exhibited mild to moderate hypercalcemia (range $9.4-12.7 \mathrm{mg} / \mathrm{dl}$ ) (25). Notwithstanding

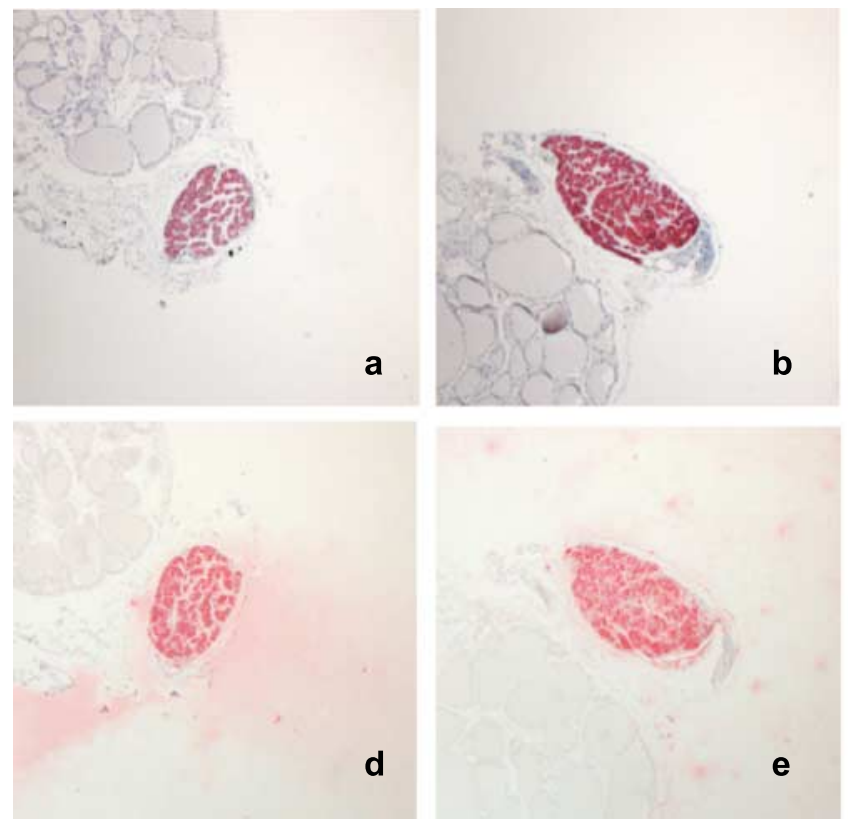

the fact that this previous clinical study (25) reported a suppressive effect of calcimimetic on serum Ca in patients with primary hyperparathyroidism, it is crucial to investigate its action since the effect of these compounds might be attenuated because the decreased parathyroid CaR may have already been activated by hypercalcemia. Notably, in this murine study we demonstrated a correlation between the effect of cinacalcet and the expression level of $\mathrm{CaR}$ in parathyroid glands. However, it is of interest that increasing the dose of cinacalcet $\mathrm{HCl}$ could overcome the resistance of CaR activation.

A previous study (18) reported that, in normal rats, administration of cinacalcet $\mathrm{HCl}$ at 3 and $10 \mathrm{mg} / \mathrm{kg}$ significantly suppressed ionized $\mathrm{Ca}$ levels between 1 and $8 \mathrm{~h}$ after administration, and levels returned to basal values by $24 \mathrm{~h}$. Although ionized Ca levels did not return to basal levels by $24 \mathrm{~h}$ at a dose of $30 \mathrm{mg} / \mathrm{kg}$ in rats (18), $100 \mathrm{mg}$ cinacalcet $\mathrm{HCl} / \mathrm{kg}$ could not suppress Ca levels at $24 \mathrm{~h}$ in mice in this study, indicating that the elimination rate of cinacalcet $\mathrm{HCl}$ in mice appears to be faster than in rats. A larger dose of cinacalcet $\mathrm{HCl}$ was necessary to suppress serum Ca levels in mice compared with rats, so we decided to administer cinacalcet $\mathrm{HCl}$ at both 30 and $100 \mathrm{mg} / \mathrm{kg}$ to mice in our experiments, this being enough to decrease serum levels $2 \mathrm{~h}$ after administration.

The suppressive effect of cinacalcet $\mathrm{HCl}$ on serum $\mathrm{Ca}$ in 65- to 85-week-old PC2 mice was observed using a single administration of $30 \mathrm{mg}$ cinacalcet $\mathrm{HCl} / \mathrm{kg}$, despite the decrease in parathyroid CaR expression and putatively ongoing CaR-mediated signaling due to hypercalcemia in these mice. These data indicated that cinacalcet $\mathrm{HCl}$ could be an effective drug for primary hyperparathyroidism even under hypercalcemic conditions. Type II calcimimetic compounds such as

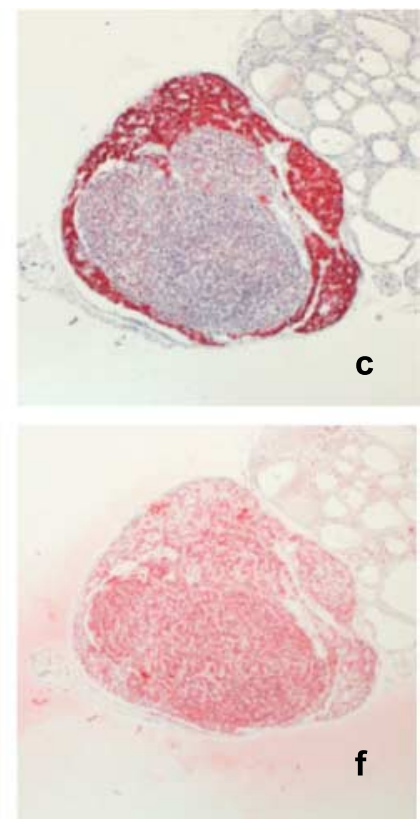

Figure 4 Immunohistochemical analyses of $\mathrm{CaR}$ and PTH expression. Parathyroid glands obtained from 65 - to 85-week-old WT $(\mathrm{a}, \mathrm{d})$ and PC2 mice (b, c, e, f) were used. Parathyroid glands were stained with anti-CaR antibody $(\mathrm{a}, \mathrm{b}, \mathrm{c})$ and antiPTH antibody (d, e, f). 


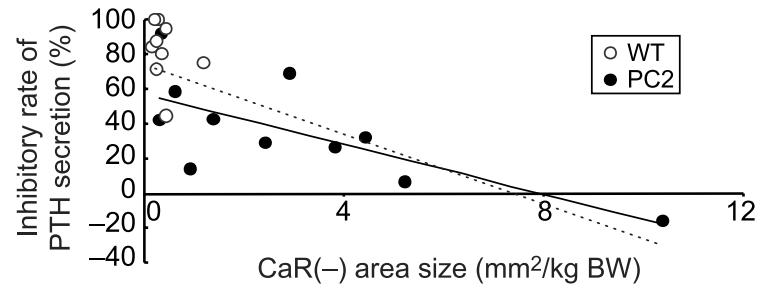

Figure 5 Correlation between the inhibitory rate of PTH secretion and $\mathrm{CaR}$ reduced $(\mathrm{Ca}-)$ area size. The sizes of the reduced CaR expression areas exhibited significant negative correlations with the inhibitory rates of PTH secretion induced by $30 \mathrm{mg}$ cinacalcet $\mathrm{HCl} / \mathrm{kg}$ administration in PC2 mice only $(r=-0.717$, $P=0.011$, solid line) and in PC2 plus WT mice $(r=-0.751$, $P<0.001$, dotted line).

cinacalcet $\mathrm{HCl}$ are allosteric modulators that bind to a different site on the CaR than that used by ionized $\mathrm{Ca}$ $(31,32)$, allowing cinacalcet $\mathrm{HCl}$ to increase $\mathrm{CaR}$ sensitivity to $\mathrm{Ca}$ ions and to suppress PTH secretion.

To analyze whether the expression of CaR, the target of cinacalcet $\mathrm{HCl}$, on parathyroid glands might be involved in the potency of cinacalcet HCl's suppression of serum $\mathrm{Ca}$ and PTH, immunohistochemical examination of $\mathrm{CaR}$ expression was performed on the parathyroid glands of mice that had been subjected to cinacalcet $\mathrm{HCl}$ administration. In the parathyroid glands of PC2 mice, which had mild to moderate primary hyperparathyroidism, tiny areas of reduced CaR expression, containing a couple of parathyroid cells, were dotted within their parathyroid glands (Fig. 4b,e). Some mice with moderate to severe hyperparathyroidism exhibited asymmetrical parathyroid glands. Such asymmetrical parathyroid glands contained focal regions encapsulated like adenomas. On such adenomatous regions, CaR expression was reduced in a reciprocal manner with the increased expression of PTH (Fig. 4c,f). The inhibition of PTH secretion by $30 \mathrm{mg}$ cinacalcet $\mathrm{HCl} / \mathrm{kg}$ exhibited significant and negative correlation with the size of the area of reduced $\mathrm{CaR}$ expression (Fig. 5), suggesting the importance of reduced CaR expression in the development of resistance of parathyroid glands to calcimimetics.

Older PC mice (93-99 weeks old) exhibited primary hyperparathyroidism in a more severe form than younger PC mice (65-85 weeks old) (Table 1). In these mice with advanced hyperparathyroidism, administration of $30 \mathrm{mg}$ cinacalcet $\mathrm{HCl} / \mathrm{kg}$ was no longer effective, as evidenced by the lack of its effect on the suppression of serum Ca and PTH levels (Fig. 6). The mechanism by which $30 \mathrm{mg}$ cinacalcet $\mathrm{HCl} / \mathrm{kg}$ lost its effect in these mice might be explained by the remarkable reduction in $\mathrm{CaR}$ in the parathyroid glands. Although these mice were resistant to $30 \mathrm{mg}$ cinacalcet $\mathrm{HCl} / \mathrm{kg}$, an increased dose of $100 \mathrm{mg} / \mathrm{kg}$ significantly suppressed both serum Ca and PTH (Fig. 6). The suppressive ratio on PTH secretion of $30 \mathrm{mg}$ cinacalcet $\mathrm{HCl} / \mathrm{kg}$ administration in younger mice was similar as that of $100 \mathrm{mg} / \mathrm{kg}$ in older mice. These phenomena strongly suggested that increasing the dose of cinacalcet $\mathrm{HCl}$ could activate the signal transduction pathway to suppress PTH secretion via $\mathrm{CaR}$, even though the expression of CaR on a parathyroid cell per se, the target of this compound, was extremely reduced. Further study of this in vivo model is desirable to examine the longterm effect of this compound in potentially preventing parathyroid cell proliferation and improving skeletal and cardiovascular complications.

In summary, a negative correlation between the potency of cinacalcet $\mathrm{HCl}$ and $\mathrm{CaR}$ expression in parathyroid glands suggested that cinacalcet $\mathrm{HCl}$ exerts its effect via $\mathrm{CaR}$ and that the potency of cinacalcet $\mathrm{HCl}$ depends on the degree of CaR expression. Even in the CaR hypo-expression state induced by severe hyperparathyroidism, the resistance to CaR activation could be overcome by increasing the dose of cinacalcet $\mathrm{HCl}$.

In conclusion, the $\mathrm{CaR}$ is a potentially useful target for a therapeutic agent like cinacalcet $\mathrm{HCl}$ to suppress PTH secretion, even though the CaR expression was reduced in parathyroid glands, which was observed in advanced primary and secondary hyperparathyroidism.

\section{Acknowledgements}

We are very grateful to Dr Karen J Krapcho (NPS Pharmaceuticals) for providing us with the 4638 polyclonal antibody and to Dr Dave Martin (Amgen Inc.) for critical discussion.
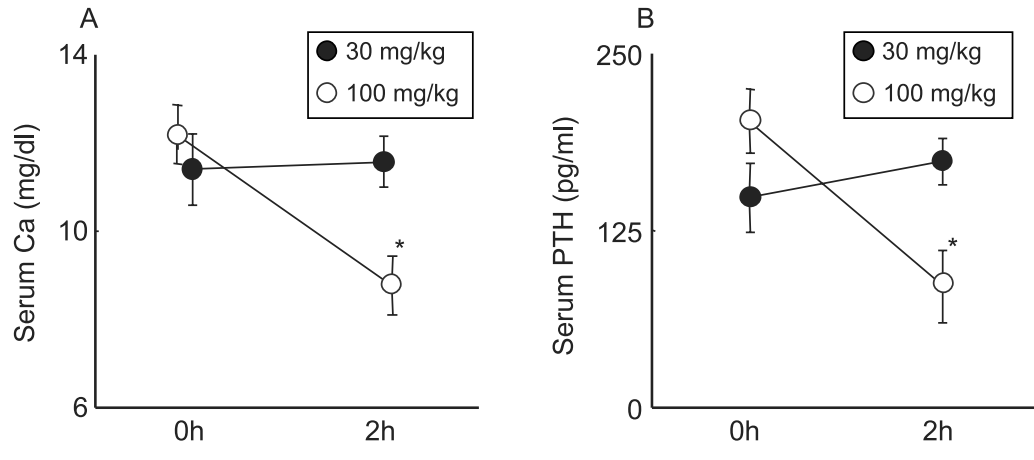

Figure 6 Effect of bolus administration of cinacalcet $\mathrm{HCl}(30 \mathrm{mg} / \mathrm{kg}$ or $100 \mathrm{mg} / \mathrm{kg})$ on serum levels of $\mathrm{Ca}(\mathrm{A})$ and $\mathrm{PTH}(\mathrm{B})$ in 93- to 99-week-old PC2 mice. Values represent means \pm S.E., $n=8$. * $P<0.05$ compared with $\mathrm{O} \mathrm{h}$ (Wilcoxon single rank test). 


\section{References}

1 Motokura T, Bloom T, Kim HG, Juppner H, Ruderman JV, Kronenberg HM \& Arnold A. A novel cyclin encoded by a bcl1linked candidate oncogene. Nature 1991350 512-515.

2 Chandrasekharappa SC, Guru SC, Manickam P, Olufemi SE, Collins FS, Emmert-Buck MR, Debelenko LV, Zhuang Z, Lubensky IA, Liotta LA, Crabtree JS, Wang Y, Roe BA, Weisemann J, Boguski MS, Agarwal SK, Kester MB, Kim YS, Heppner C, Dong Q, Spiegel AM, Burns AL \& Marx SJ. Positional cloning of the gene for multiple endocrine neoplasia-type 1 . Science 1997276 404-407.

3 Imanishi Y \& Tahara H. Putative parathyroid tumor suppressor on 1p: independent molecular mechanisms of tumorigenesis from 11q allelic loss. American Journal of Kidney Disease 2001 38 S165-S167.

4 Palanisamy N, Imanishi Y, Rao PH, Tahara H, Chaganti RS \& Arnold A. Novel chromosomal abnormalities identified by comparative genomic hybridization in parathyroid adenomas. Journal of Clinical Endocrinology and Metabolism $1998 \mathbf{8 3}$ 1766-1770.

5 Hosokawa Y, Pollak MR, Brown EM \& Arnold A. Mutational analysis of the extracellular $\mathrm{Ca}(2+)$-sensing receptor gene in human parathyroid tumors. Journal of Clinical Endocrinology and Metabolism $1995803107-3110$.

6 Cetani F, Pinchera A, Pardi E, Cianferotti L, Vignali E, Picone A, Miccoli P, Viacava P \& Marcocci C. No evidence for mutations in the calcium-sensing receptor gene in sporadic parathyroid adenomas. Journal of Bone Mineral Research 199914 878-882.

7 Kifor O, Moore FD Jr, Wang P, Goldstein M, Vassilev P, Kifor I, Hebert SC \& Brown EM. Reduced immunostaining for the extracellular $\mathrm{Ca}^{2+}$-sensing receptor in primary and uremic secondary hyperparathyroidism. Journal of Clinical Endocrinology and Metabolism 199681 1598-1606.

8 Gogusev J, Duchambon P, Hory B, Giovannini M, Goureau Y, Sarfati E \& Drueke TB. Depressed expression of calcium receptor in parathyroid gland tissue of patients with hyperparathyroidism. Kidney International $199751328-336$.

9 Brown EM, Gamba G, Riccardi D, Lombardi M, Butters R, Kifor O, Sun A, Hediger MA, Lytton J \& Hebert SC. Cloning and characterization of an extracellular $\mathrm{Ca}(2+)$-sensing receptor from bovine parathyroid. Nature 1993366 575-580.

10 Brown EM \& MacLeod RJ. Extracellular calcium sensing and extracellular calcium signaling. Physiological Reviews 200181 239-297.

11 Ho C, Conner DA, Pollak MR, Ladd DJ, Kifor O, Warren HB, Brown EM, Seidman JG \& Seidman CE. A mouse model of human familial hypocalciuric hypercalcemia and neonatal severe hyperparathyroidism. Nature Genetics 199511 389-394.

12 Imanishi Y, Hosokawa Y, Yoshimoto K, Schipani E, Mallya S, Papanikolaou A, Kifor O, Tokura T, Sablosky M, Ledgard F, Gronowicz G, Wang TC, Schmidt EV, Hall C, Brown EM, Bronson R \& Arnold A. Primary hyperparathyroidism caused by parathyroid-targeted overexpression of cyclin D1 in transgenic mice. Journal of Clinical Investigation $2001 \mathbf{1 0 7}$ 1093-1102.

13 Bilezikian JP, Potts JT Jr, Fuleihan Gel H, Kleerekoper M, Neer R, Peacock M, Rastad J, Silverberg SJ, Udelsman R \& Wells SA. Summary statement from a workshop on asymptomatic primary hyperparathyroidism: a perspective for the 21st century. Journal of Clinical Endocrinology and Metabolism $2002 \mathbf{8 7}$ 5353-5361.

14 Khosla S, Melton LJ 3rd, Wermers RA, Crowson CS, O'Fallon W \& Riggs B. Primary hyperparathyroidism and the risk of fracture: a population-based study. Journal of Bone Mineral Research 199914 1700-1707.

15 Rossini M, Gatti D, Isaia G, Sartori L, Braga V \& Adami S. Effects of oral alendronate in elderly patients with osteoporosis and mild primary hyperparathyroidism. Journal of Bone Mineral Research $200116113-119$.
16 Selby PL \& Peacock M. Ethinyl estradiol and norethindrone in the treatment of primary hyperparathyroidism in postmenopausal women. New England Journal of Medicine $1986 \mathbf{3 1 4}$ $1481-1485$.

17 Nemeth EF, Steffey ME, Hammerland LG, Hung BC, Van Wagenen BC, Del Mar EG \& Balandrin MF. Calcimimetics with potent and selective activity on the parathyroid calcium receptor. PNAS 199895 4040-4045.

18 Nemeth EF, Heaton WH, Miller M, Fox J, Balandrin MF, Van Wagenen BC, Colloton M, Karbon W, Scherrer J, Shatzen E, Rishton G, Scully S, Qi M, Harris R, Lacey D \& Martin D. Pharmacodynamics of the type II calcimimetic compound cinacalcet $\mathrm{HCl}$. Journal of Pharmacology and Experimental Therapeutics $2004 \mathbf{3 0 8}$ 627-635.

19 Antonsen JE, Sherrard DJ \& Andress DL. A calcimimetic agent acutely suppresses parathyroid hormone levels in patients with chronic renal failure. Rapid communication. Kidney International $199853223-227$.

20 Goodman WG, Frazao JM, Goodkin DA, Turner SA, Liu W \& Coburn JW. A calcimimetic agent lowers plasma parathyroid hormone levels in patients with secondary hyperparathyroidism. Kidney International $2000 \mathbf{5 8} 436-445$.

21 Goodman WG, Hladik GA, Turner SA, Blaisdell PW, Goodkin DA, Liu W, Barri YM, Cohen RM \& Coburn JW. The calcimimetic agent AMG 073 lowers plasma parathyroid hormone levels in hemodialysis patients with secondary hyperparathyroidism. Journal of the American Society of Nephrology 2002 13 1017-1024.

22 Quarles LD, Sherrard DJ, Adler S, Rosansky SJ, McCary LC, Liu W, Turner SA \& Bushinsky DA. The calcimimetic AMG 073 as a potential treatment for secondary hyperparathyroidism of endstage renal disease. Journal of the American Society of Nephrology $200314575-583$.

23 Block GA, Martin KJ, de Francisco AL, Turner SA, Avram MM, Suranyi MG, Hercz G, Cunningham J, Abu-Alfa AK, Messa P, Coyne DW, Locatelli F, Cohen RM, Evenepoel P, Moe SM, Fournier A, Braun J, McCary LC, Zani VJ, Olson KA, Drueke TB \& Goodman WG. Cinacalcet for secondary hyperparathyroidism in patients receiving hemodialysis. New England Journal of Medicine $20043501516-1525$.

24 Silverberg SJ, Bone HG 3rd, Marriott TB, Locker FG, Thys-Jacobs S, Dziem G, Kaatz S, Sanguinetti EL \& Bilezikian JP. Short-term inhibition of parathyroid hormone secretion by a calcium-receptor agonist in patients with primary hyperparathyroidism. New England Journal of Medicine 1997337 1506-1510.

25 Shoback DM, Bilezikian JP, Turner SA, McCary LC, Guo MD \& Peacock M. The calcimimetic cinacalcet normalizes serum calcium in subjects with primary hyperparathyroidism. Journal of Clinical Endocrinology and Metabolism $2003 \mathbf{8 8}$ $5644-5649$.

26 Nagano N, Miyata S, Obana S, Ozai M, Kobayashi N, Fukushima N, Burke SK \& Wada M. Sevelamer hydrochloride (Renagel), a non-calcaemic phosphate binder, arrests parathyroid gland hyperplasia in rats with progressive chronic renal insufficiency. Nephrology Dialysis Transplantation $2001 \quad 16$ $1870-1878$.

27 Imanishi Y, Koyama H, Inaba M, Okuno S, Nishizawa Y, Morii H \& Otani S. Phosphorus intake regulates intestinal function and polyamine metabolism in uremia. Kidney International $1996 \mathbf{4 9}$ 499-505.

28 Wada M, Furuya Y, Sakiyama J, Kobayashi N, Miyata S, Ishii H \& Nagano N. The calcimimetic compound NPS R-568 suppresses parathyroid cell proliferation in rats with renal insufficiency. Control of parathyroid cell growth via a calcium receptor. Journal of Clinical Investigation $1997 \quad \mathbf{1 0 0}$ 2977-2983.

29 Wada M, Nagano N, Furuya Y, Chin J, Nemeth EF \& Fox J. Calcimimetic NPSR-568 prevents parathyroid hyperplasia in rats with severe secondary hyperparathyroidism. Kidney International 2000 $\mathbf{5 7} 50-58$. 
30 Wada M \& Nagano N. Control of parathyroid cell growth by calcimimetics. Nephrology Dialysis Transplantation 200318 (Suppl 3) iii13-iii17.

31 Hammerland LG, Garrett JE, Hung BC, Levinthal C \& Nemeth EF Allosteric activation of the $\mathrm{Ca}^{2+}$ receptor expressed in Xenopus laevis oocytes by NPS 467 or NPS 568. Molecular Pharmacology 199853 1083-1088.

32 Hauache OM, Hu J, Ray K, Xie R, Jacobson KA \& Spiegel AM. Effects of a calcimimetic compound and naturally activating mutations on the human $\mathrm{Ca}^{2+}$ receptor and on $\mathrm{Ca}^{2+}$ receptor/ metabotropic glutamate chimeric receptors. Endocrinology 2000 $1414156-4163$.

Received 23 May 2005

Accepted 19 July 2005 